\title{
VIOLATING FOOD SYSTEM WORKERS' RIGHTS IN THE TIME OF COVID-19: THE QUEST FOR STATE ACCOUNTABILITY
}

\author{
Hilal Elver and Melissa Shapiro
}

\begin{abstract}
Food system workers, accounting for nearly one-third of the global workforce, are vital to the universal realization of the right to food, yet face formidable barriers to the realization of their own rights. Despite state obligations to protect, respect, and fulfil the rights of workers under international human rights law, gaps in legal frameworks and lack of political will have left food system workers exposed to discrimination and abuse at the hands of private actors. Migrant workers, as well as racial and ethnic minorities, in particular, face targeted exploitation without redress. Case studies demonstrate the extent of this harm, even as governments designate workers as "essential" during the COVID-19 pandemic. The authors of this article argue that deliberate inaction by states to extend meaningful protections to workers or indict exploitative actors demonstrates the need for a new state crime-one that holds accountable governments that are complicit in the grave violations of workers' fundamental rights.
\end{abstract}

Keywords: rights; food; workers; COVID-19

\section{Introduction}

Food system ${ }^{1}$ workers are an underappreciated but vital part of food security that support state efforts to guarantee the realisation of human rights, including the right to food. ${ }^{2}$ At the same time, food system workers tend to be among the most food insecure, facing formidable barriers to the realisation of their own rights (Elver 2018). Migrant workers, especially those who are undocumented, and workers who are racial and ethnic minorities, are more likely to be subject to precarious conditions. These workers are exceptionally vulnerable, lacking adequate safeguards administered at state and local levels (Elver 2018). This reality suggests that states are failing to satisfy the standards set forth in the International Covenant of Economic, Social and Cultural Rights (ICESCR), which obligates states to guarantee fundamental human rights "without discrimination of any

Hilal Elver, Former UN Special Rapporteur on the right to food (2014-2020); UCLA School of Law Melissa Shapiro, Harvard Law School Food Law and Policy Clinic 
kind as to race, colour, sex, language, religion, political or other opinion, national or social origin, property, birth or other status." (United Nations General Assembly 1966a: 3)

The authors of this article have previously recognized the deliberate inaction of states to implement adequate safeguards for food system workers, consistent with this obligation. In principle, private sector actors in control of the world's everyexpanding supply chains also bear responsibility to monitor and enforce against exploitation; (United Nations Committee on Economic, Social and Cultural Rights 1999: 20) in reality, today's food systems are co-opted by a handful of corporate actors that have converted economic wealth into direct political influence over government agenda setting (Elver 2018: 10). States, corrupted or at least compromised by this influence, are not adopting the meaningful monitoring and enforcement mechanisms that would hold these corporations responsible for rights violations. Instead, governments are turning a blind eye towards the corporate abuse of power and endorsing the status quo through public-private partnerships (Elver 2020: 69). This solidarity with those private sector actors disregarding the fundamental rights of food system workers signals to the rest of civil society that such behaviour is not only morally acceptable, but legally permissible.

States are more than complicit in the abuse that food system workers encounter, as many rights violations are perpetuated as a result of fragmented legal frameworks and unratified agreements. Moreover, ineffective implementation of existing international and national laws is commonplace, and often expressive of a weak or non-existent political will. ${ }^{3}$ The result is large gaps in the provision of meaningful protections of fundamental rights, especially for the most vulnerable. International human rights law and instruments of the International Labour Organization (ILO) set the standards for states to follow. But both international and national frameworks fall far short of offering comprehensive and enforceable protections for those employed in the food and agricultural sector.

Even if states recognize that food system workers are, in principle, entitled to legal protections, the prevalence of informality in the sense of unregistered and non-unionized labour, hinders the efficacy of relevant laws, and prevents workers from accessing rights. The result of this condition, once again, is a lack of social protections and access to justice for many workers, especially those who are undocumented. This failure of protection is accentuated by widespread impunity accorded to state actors that impose or ignore xenophobic practices and systemic discrimination.

The outbreak of the COVID-19 pandemic, which has devastated food systems around the world ${ }^{4}$ (Food and Agriculture Organization of the United Nations et al. 2020a) has forced states to acknowledge the importance of all supply chain workers, a population to whom fundamental human rights extend. States have issued 
emergency declarations confirming the "essential status" of food system workers in light of supply chain disruptions and spikes in food prices that resulted in food insecurities and hunger for consumers (Jordan 2020). And yet, this newfound recognition has not led to meaningful strengthening of worker protection, especially for those who are undocumented or are otherwise subject to discriminatory employment practices. Rather, governments are presenting workers who harvest, process, and distribute food with an impossible choice: risk their livelihoods or risk their lives.

That food system workers should be forced into this position reveals what many have known for some time - that many food system workers are trapped in structures of modern slavery, which is characterized by persistent and severe human rights abuses, as well as by violations of fundamental labour rights. This abusive situation is widespread in many countries; it existed before the pandemic and will likely persist after it subsides.

In the following sections, the authors illustrate the need for an international and national upsurge of civic and judicial activism, as well as the criminalization of intentional state complicity in the deliberate or grossly negligent private sector abuse of food system workers. The authors do so, first, by reviewing existing international human rights and labour rights protections designed to cover food system workers before the COVID-19 conditions, and addressing the gaps in these protections. This analysis features some illustrative case studies to illustrate the acute exploitation experienced by the most marginalized workers.

The article then focuses on the impact of COVID-19, drawing attention to the heightened abuse that food system workers have faced throughout the pandemic, despite issues of food worker abuse receiving greater recognition by states. The authors subsequently argue that legal actions brought by food system workers alleging discrimination based on, or which implicate, migrant or minority status, are too far and few between to generate meaningful change or close present protection gaps.

As this narrative progresses, the authors encourage readers to recall that states have an unconditional obligation to respect, protect, and fulfil all international human rights norms without any discrimination. The obligation requires not only negative action (respect), but also positive action to ensure that all food system workers receive the full human rights and labour rights protections to which they are legally entitled. This article aims to demonstrate that realizing rights of workers must require a major transformation in how states regard these obligations: first, by reframing official complicity that could bring criminal responsibility as a result of inhumane and abusive treatment of these workers at the hands of various actors; and then, by accepting official complicity in such actions that constitute 
grave violations of human rights for all actors, including those businesses dominating global food systems.

The authors ultimately propose a new category of state crime, one that is founded on a human rights-based approach to criminalization, rather than a strict understanding of criminal responsibility. Serious consideration should also be given to adding the most egregious violations of workers' rights to the list of crimes against humanity, provided such action is supported by member states of the International Criminal Court and reinforced by interested non-governmental organizations (NGOs) and civil society activists.

\section{Protections for Food System Workers Under International Law}

\section{International Human Rights Law}

Food system workers play a critical role in achieving global food security and enable states to progressive realization of fundamental human rights, notably, the right to food. The right to food is derived from article 25 of the Universal Declaration of Human Rights (UDHR) (United Nations General Assembly 1948) and further elaborated in article 11 of the International Covenant on Economic, Social and Cultural Rights (ICESCR) (United Nations General Assembly 1966b: 3). To date, 171 countries have ratified the ICESCR, thus formally recognizing obligations to respect, protect, and fulfil the rights contained therein (United Nations General Assembly 1966a: 3).

The right to adequate food is realized only when every man, woman, and child, alone or in community with others, have physical and economic access at all times to adequate food or means for its procurement. The normative content of the right to adequate food is often distilled into five main pillars: availability, accessibility, utilization, and stability, along with the sustainability. The most recent High Level Panel of Experts on Food Security and Nutrition Report (2020: xv) suggests an additional concept of "agency" referring to the capacity of individuals or groups to make their own decision about what food they eat, what food they produce, how that food is produced, processed, and distributed within food systems, and their ability to engage in processes that shape food system policies and governance. Yet food system workers are often excluded from critical analyses of these tenets.

The Committee on Economic, Social and Cultural Rights has affirmed that the adequate food is indivisibly linked to the inherent dignity of the human person and is indispensable for the fulfilment of other human rights enshrined in the International Bill of Human Rights (United Nations Committee on Economic, Social and Cultural Rights 1999: 4). Such interrelated rights include those that are 
often unrealized for those employed in the food and agricultural sector, including rights to just and favourable conditions for decent work, which provides for a "living wage," (articles 6 and 7 of the ICESCR) adequate living conditions, and social protections, including social security (article 9 of the ICESCR) (United Nations General Assembly 1966c: 3). States also have an obligation to guarantee the right to the highest attainable standard of health, pursuant to article 12 of the ICESCR (United Nations General Assembly 1966d: 3). In its General Comment No. 14, the Committee embraced the notion that this right extends to the underlying determinants of health, including adequate food, potable water, and safe working conditions for all workers (United Nations Committee on Economic, Social and Cultural Rights 2000).

Despite these obligations, states have generally prioritized the protection and enforcement of civil and political rights over economic, social, and cultural rights, as evidenced by the fact that many rights contained in the ICESCR, including the right to food, have not been mainstreamed into national legal systems. The most important reason of this unequal treatment is the "progressive realization" clause of the ICESCR (Art. 2/1), mandating states "to take steps" to the extent of their available resources to progressively achieve the full realization of economic, social, and cultural rights. This clause has effectively permitted states to relax policies intended to protect economic, social, and cultural rights, especially in furtherance of free-market interests that dominates the global economic order.

While states that are party to the ICESCR bear the primary duty to progressively realize the right to food for all rights-holders, all states and all members of society, including the private business sector and municipal governmental authorities, have responsibilities to act uphold compliance with fundamental human rights (United Nations Committee on Economic, Social and Cultural Rights 1999: 20). This notion of collective action is the cornerstone of the 2030 Agenda for Sustainable Development, which calls upon all stakeholders, from every corner of society, to ensure that "no one is left behind" (United Nations General Assembly 2015). Multi-stakeholder action is evermore important for the realization of workers' human rights, which is often an issue of social justice (United Nations Committee on Economic, Social and Cultural Rights 1999: 4). Nevertheless, the 2030 Agenda for Sustainable Development, like many other social covenants, has no monitoring and accountability mechanisms. Governments should be legally obliged to recognize that the human rights of this population, in particular, is a multi-sectoral, multi-faceted issue, one which requires appropriate economic, environmental, and social policies to be adopted at the international, national, and local levels (United Nations Committee on Economic, Social and Cultural Rights 1999: 4). 


\section{International labour law}

Such "appropriate" policies include those that fall within and are derived from international labour law. Labour rights and human rights are interdependent, indivisible, and mutually inclusive; as members of a defined workforce, food system workers are entitled to additional labour protections, the full enjoyment of which is a necessary precondition to the realization of the right to food (Elver 2018: 27). These worker protections are generally contained within eight core conventions of the ILO, ${ }^{5}$ the only tripartite agency in the United Nations common system, with the government, employer, and worker representatives.

The ILO has also produced several conventions that are pertinent to food system workers, including: The Right of Association (Agriculture) Convention, 1921 (No. 11); Forced Labour Convention, 1930 (No. 29) and its Protocol of 2014 and Trafficking of Persons Protocol; Minimum Wage Fixing Machinery (Agriculture) Convention, 1951 (No. 99) and recommendation No. 89; Plantations Convention, 1958 (No. 110) and recommendation No. 110; Protocol of 1982 to the Plantations Convention, 1958 (No. 110); Labour Inspection (Agriculture) Convention, 1969 (No. 129); Rural Workers' Organisations Convention, 1975 (No. 141) and recommendation No. 149; Indigenous and Tribal Peoples Convention, 1989 (No. 169) and recommendation No. 104 (1957); Safety and Health in Agriculture Convention, 2001 (No. 184) and recommendation No. 192; Work in Fishing Convention, 2007 (No. 188) and recommendation No. 199. ILO also has a series of guidance notes that cover the implementation of the above-listed issues.

Most of these instruments extend protections to those working upstream in the food supply chain, i.e. during the harvest, processing, and distribution phases, but ILO has not developed a specific instrument that provides comprehensive labour standards for all food system workers. Instruments that pertain to working conditions in restaurants are also somewhat outdated and require revision to take account of new methods of food delivery and distribution, especially given the increased demand during the COVID-19. In the past few decades, ILO has sporadically issued documents addressing protections and decent work in the food and drink sectors as well as global supply chains. Since the outbreak of COVID-19, ILO has also given specific attention to the situation of migrant workers, including those employed in the food and agricultural sector. ${ }^{6}$

\section{Gaps in Legal Protections}

Despite protective frameworks developed at the international level, food system workers remain among the most vulnerable to discriminatory employment practices and human rights violations. Fragmentation and gaps within the aforementioned 
legal protections and high rates of informality among food system employees leave these workers exposed to dangerous, unsafe, and occasionally lethal working conditions and provide almost no avenues for effective redress. For example, the ILO Work in Fishing Convention, 2007 (No. 188) sets basic standards of decent work for the 38 million workers employed on commercial fishing vessels; yet, the Convention includes several "flexibility clauses" intended to ease the burden on ILO member states, but which ultimately limit the scope of protections (International Labour Organization 2007). For example, the Convention applies (by default) only to vessels greater than $24 \mathrm{~m}$, or 10 percent of all fishing vessels; ${ }^{7}$ the Convention also does not extend to shore-based workers, such as those employed in land-based aquaculture or processing facilities.

These gaps leave many of those employed in the fishery sector without comprehensive protections, unless states take active steps to adopt more expansive laws at the national level. Besides these gaps, the most important ILO Conventions for workers are usually ratified by only a handful of states. ${ }^{8}$ This reveals the reluctance of states to not just recognize the inherent rights of workers, but to commit to protecting these rights at any cost. Even if ratified, the lack of implementation at a state level remains non-existent or severely deficient in most participating countries.

Both at sea and on land, many food system workers are further exposed to rights violations and abuse due to the informal employment status. The term "informal economy" refers to "all economic activities by workers and economic units that are - in law or in practice - not covered or insufficiently covered by formal arrangements" (International Labour Organization 2018: 132). The agricultural sector features the highest level of informal employment, ranging from 60 percent to 90 percent globally (International Labour Organization 2018). In fact, informal and casual work arrangements (for example, part-time, short-term or temporary contracts, on-call schedules, multi-layered subcontracts or franchises, and self-employment schemes, etc.) have become commonplace in global supply chains, as the corporate food system regime prioritizes efficiency and cost-saving measures, often at the expense of workers.

The dangers of informal employment for food system workers cannot be overstated: for the two billion people, or more than 61 percent of the world's population, employed in the informal economy, there is no guarantee that states will protect, respect, or fulfil rights of social protection, decent work, and collective bargaining. This means that informal workers are subject to dangerous and precarious employment and are without redress in the event of rights violations. During the pandemic, which diminished working hours by 12.1 percent, or the equivalent of 345 million full-time equivalent jobs worldwide in the third quarter, failure to guarantee these rights for informal workers means that this population group faces a higher and disproportionate risk of slipping into poverty (International 
Labour Organization 2020). The ILO has recognized that those who make their living in the informal economy, especially in the food service industry, are likely to be hit the hardest, and will need income support or other financial assistance from the state (International Labour Organization 2020b).

These impacts are not homogeneous among food system workers: migrant workers, especially those who are undocumented or without permanent resident status, are more likely to be impacted by informal arrangements and gaps in legal protections. Migrant workers are also more likely to experience discrimination and exploitation when compared with their national counterparts (Elver 2018). Workers without proper documentation or with stringent work requirements do their jobs while facing threats of detention or deportation, are therefore less likely to collectively bargain or advocate on behalf of their rights.

Workers of minority race and ethnicity, more broadly, also tend to experience targeted attacks by employers and receive fewer protections at the national level. A recent study of worker protections in UN member states, for example, confirmed that workers in nearly one in four member states are not protected from discrimination based on race and ethnicity (UCLA World Policy Analysis Centre 2020). The section below offers examples that highlight how this discrimination has undermined the health and wellbeing of food system workers; and, as discussed later in this article, how calls for racial justice during the COVID-19 pandemic have brought racist and discriminatory practices of some states and private sector actors into public view.

\section{Evidence of Persistent Mistreatment and Abuse among Food System Workers}

The failure of existing legal frameworks to effectively protect food system workers is not merely speculative: case studies from around the world have revealed inhumane working conditions and government neglect, especially of undocumented migrant workers and racial minorities, and as mentioned, especially in the informal economy. Undocumented workers are likely to suffer the most severe forms of labour abuse, including contemporary forms of slavery such as forced labour, bonded labour, and human trafficking.

In addition to the general human rights and labour rights frameworks discussed above, the international community has set forth specific protections for migrants and racial minorities, including those contained in the International Convention on the Protection of Rights of All Migrant Workers and Members of Their Families (1990) and the International Convention on the Elimination of All Forms of Racial Discrimination (1969), respectively. Nevertheless, workers from these populations employed in the food and agricultural sector continue to 
experience slavery-like conditions and discrimination around the world as the standards are not implemented; perpetrators of the most gross violations almost never face adverse consequences for such actions.

\section{Case study: Europe}

In several member countries of the European Union, migrant workers are being grossly underpaid and overworked, isolated, threatened and beaten, and forced to live in toxic, inhumane conditions. Many exploited workers fill dangerous jobs on farms and are essential for production and harvest, yet are largely invisible to the state. Exploitation often starts with false promises and fraud during the hiring process, with workers soon enduring extreme conditions and apparent violations of labour rights (European Union Agency for Fundamental Rights 2019).

The European Union Common Agricultural Policy (CAP) which accounts for over a third of the block's budget aims to support farm owners (1.6 million) and pumps nearly $€ 60$ billion into the sector each year. The working conditions of those employed by these farms, however, are not even mentioned in the subsidies scheme. This is an indication that member states pursue policy agendas that ignore food systems workers' fundamental human rights, despite that fact that such workers are the backbone of the EU's giant agricultural sector. This is also further proof that the neoliberal economic order enables corporations to lobby EU decisionmakers to protect profitability rather than workers.

Among the most severe cases of exploitation are those reported in Italy, where hundreds of thousands of migrants make up an essential component of the labour market. Italy has increased its reliance on migrant farmworkers over the past three decades, as it has shifted from family labour to more intensive agricultural production and externally sourced workers in an effort to compete with corporate agrifood chains (Corrado 2018). The incidence of migrant workers in the agricultural sector has tripled over the last ten years, increasing from 5.3 percent in 2007 to 16.6 percent in 2017 of the total agricultural workforce (International Committee of the Red Cross 2019: 4). Migrant workers, mostly from North Africa and Eastern Europe, remain trapped in the violent Caparolato (gangmastering) system, living in a constant state of invisibility and fear.

This abusive Caporalato system is an illegal intermediation between workers and farmers and is composed of modern slavery-like conditions, for example, with salaries below minimum wage; working hours exceeding national limits; lack of social security or social protections; unhealthy living conditions; moral and physical violence; and forced pay for water, transportation, and food. ${ }^{9}$ Workers in such precarious situations do not have the agency to seek alternative employment or to escape from these arrangements. Thus, many workers acquiesce to exploitative, 
irregular arrangements, believing that there is no alternative option but to accept overcrowded accommodation, scarce access to water, and little to access to electricity, sanitation or basic necessities.

In 2016, Italy adopted Law 199/2016 against labour exploitation, which extends to the Caporalato system. The law criminalizes the system, imposing sanctions on both the intermediary and the "patron" who exploits workers-regardless of whether there has been an illicit intermediation (Elver 2018: 56). While the law is seen by many as a step in the right direction, it is insufficient to uphold the human rights of undocumented farmworkers who are "invisible" under the law, absent greater vigilance by the state and a stronger political will to achieve compliance (Srour 2018).

Elsewhere in the EU, food system workers do not fare much better: Spain, which is Europe's leading producer of fruit and vegetables, widely employs illegal migrant workers in this sector, mostly from North Africa. For instance, in the strawberry fields in Huelva, a sector worth $€ 0.5$ billion, seasonal migrant workers receive merely $€ 40$ a day, which is much lower than minimum wage. This exploitation recently made international news when Euro News TV program interviewed several farmworkers (Borges and Huet 2020) many of whom were living in "chabolas," and experiencing below standard living conditions. Many women workers also report sexual harassment and abuse.

In France, as well, which receives more agricultural subsidies than any other member state, over $€ 7$ billion each year, the living and working conditions of seasonal workers are almost like modern slavery. In order to foster the largest agricultural sector in Europe, the state has permitted the exploitation of workers in violation of French law. Or rather, the French government has deliberately chosen to not protect against these violations, as there is no monitoring system to implement the proper laws in the book.

\section{Case study: Southeast Asia}

Abusive employment practices are often carried out beyond the reach or oversight of relevant authorities, as is the case with trafficking and forced labour among migrant fishery workers on the high seas. The most severe cases of contemporary slavery ${ }^{10}$ have been reported in South Asia, where high-ranking brokers traffic thousands of migrants from Cambodia, Lao People's Democratic Republic, and Myanmar, including women and children, to China, Indonesia, and Thailand every year. ${ }^{11}$ Vivid reports detailing accounts of the abuses on board shipping vessels have aroused deep concerns in the past decade, inciting responses from the international community. ${ }^{12}$ The International Organization for Migration (IOM), for example, has warned against recruiting Rohingya refugees in Bangladesh to serve 
as forced labour in the fishing industry with fraudulent offers of paid work (International Organization for Migration 2017).

Despite the shock of recognition, reports of abuse continue to emerge: in the summer of 2020, there were separate incidents involving deaths of Indonesian crew members on-board Chinese fishing vessels, due to exploitative labour and inhumane living conditions (South China Morning Post 2020). The Indonesia government launched an investigation into one such incident, which involved the death of four crew members on-board a Chinese-owned tuna fishing vessel between December 2019 and April 2020 (McVeigh and Firdaus 2020). The vessel was allegedly engaged in illegal fishing practices; crew members, who had been lured onto the vessel under false pretences and had their passports confiscated once on board, and were subjected to deadly living and working conditions (McVeigh and Firdaus 2020). Similar situations are likely to occur in the absence of meaningful national protections for migrant workers engaged in the fishery sector or recognition of international protective frameworks. ${ }^{13}$

\section{Case study: United States}

The criminalization of migrants, especially those in irregular situations, and the resurgence of xenophobic and racist rhetoric by governments is perhaps most apparent in the United States. In recent years, the modern debate on immigration has been characterized by misconceptions and proxy fears about unemployment, the viability of welfare systems, and other aspects of globalization. Such criminalization of migrants and minority groups violates the human rights principles of equality and non-discrimination. And yet, in the US, where many farmworkers are undocumented, there is no effective, unified government remedy for most human rights violations, because in the federal system there is a great variation in relation to protection of human rights, including workers' rights. Undocumented workers fear coming forward in the event of violations and avoid fighting for rights to assembly and association, as the threat and fear of deportation exceeds worker concerns about fundamental rights.

Minority food system workers of legal status do not fare much better: structural racism in the U.S. food system has profoundly shaped the distribution of agricultural land, resources, and wealth. ${ }^{14}$ A study revealed that between 2012 and 2014, farmers of colour (including Black, Asian, Native American, Pacific Islander, and those reporting more than one race) comprised less than 3 percent of non-farming landowners and less than 4 percent of owner-operators (Horst and Marion 2019). Latino populations comprised only about 2 percent of non-farming landowners and about 6 percent of owner and tenant operators, yet accounted for over 80 percent of farm labourers (Horst and Marion 2019: 1-16). These workers are regularly exposed to dangerous working conditions, lacking visibility or protection 
under national frameworks, including the National Labor Relations Act and Fair and Labor Standards Act (Kelkar 2016).

\section{Emerging Violations of Food System Workers' Rights During the COVID-19 Pandemic}

Since the outbreak of COVID-19, governments have no longer been able to feign ignorance as to the critical role that food system workers play in promoting global food security. Protectionist measures adopted in response to the pandemic, including border closures, immediately raised concerns about labour shortages in the agricultural sector (Harvey 2020). While food prices have remained relatively stable, transport blockages and quarantine measures have impeded access to markets (FAO et al. 2020a).

Avoiding a food price crisis is necessary to contain further fallout from the pandemic, as preliminary projections already suggest that an additional 83 to 132 million people may find themselves undernourished by the year's end (FAO et al. 2020b). According to the 2020 Global Food Crisis Report, while 135 million people are already on the threshold of hunger in the global scale, there is a possibility that this number will increase to 265 million by the end of the year, with countries in Sub-Saharan Africa and the Middle East faring the worst. According to the World Food Program president, 300,000 people may die every day due to the food crisis. The most vulnerable groups include small-scale farmers, migrants, and informal workers. Furthermore, according to the 2020 Global Food Crisis Report, approximately 75 million children in fragile countries have limited access to adequate nutrition, clean drinking water and health care to help sustain their lives; 17 million of these children struggle with acute nutritional deficiencies. Based on a recent article in Lancet Global Health Journal (Robertson 2020), UNICEF announced that because of pandemic-related malnutrition, child mortality under age five will rise by 6,000 deaths per day in next six months.

While there is no food production issue yet, the COVID-19 pandemic has clearly had a serious adverse impact on food access and availability worldwide. According to UN University research (Sumner et al. 2020) as a result of the impact of the pandemic on the global economy, at least half a billion people will be poor, with poverty reaching 8 percent of the total world population. Since 1990 there has not been such an increase on poverty. These impacts will only become worse overtime: it is predicted that if the pandemic continues, there will be a serious food shortage, especially for peoples and countries that already struggling with food insecurity (Food and Agriculture Organization 2020a).

Understanding that food systems workers are a vital part of food availability, governments have responded to this potential crisis by trying to promote a 
"business as usual scenario" for food system workers-for example, governments around the world have issued temporary orders that allow farmworkers to continue crossing borders for employment purposes. The EU has urged member states to lift travel bans for migrant workers who will help plant and harvest crops for the season (Connelly 2020). Reports confirmed thousands of chartered migrant workers from Eastern Europe landed in Germany and the United Kingdom for the season (Salyga 2020). The Farm Lobby in Australia organized calls for streamlined regulations to guarantee cheap, migrant labour, despite pandemic protections (Onselen 2020). The US exempted H-2A visas used to bring in foreign farmworkers from the wave of immigration suspension efforts of the past few months (Hesson 2020).

This unprecedented visibility for a historically overlooked population has nevertheless failed to dismantle the xenophobic, discriminatory, and dangerous systems through which these food system workers are exploited. Footage released of Italy's migrant farmworkers at the peak of COVID-19, for example, reveals the same slavery-like conditions to which these workers have long been exposed, as discussed above (Africa Report 2020). Government efforts to address these issues by regularizing and protecting migrant workers have been met with scepticism and criticism for falling short of the necessary changes (D'Agostino 2020).

There have also been new reports of food system worker abuse, with violations disproportionately targeting migrant workers (Royte 2020). Many impacted are informal workers excluded from social protections, such as health insurance and paid leave, as well as those of minority race and ethnicity. On U.S. farms, factories, and processing facilities, violations of fundamental human rights to food, health, water, and adequate housing are worse than ever (Guerrero 2020). According to a recent Centers for Disease Control study of COVID-19 outbreaks at more than 200 poultry, pork, and beef processing plants, 87 percent of infected workers were people of colour (Centers for Disease Control and Prevention 2020). Upstream in the supply chain, the reports are similarly grim, with clusters of COVID-19 cases reported among farmworker communities in Florida, California, Washington, and Tennessee (Royte 2020). Such cases serve only to confirm the lack of protections extended to those who are deemed "essential."

It is clear that the exploitation of food system workers - an issue of modern slavery-is as dangerously pervasive as the pandemic itself, warranting swift action on the part of states. Unfortunately, states are either delaying action or taking minimal steps that fail to address underlying discrimination. In March 2020, for example, the U.S. Department for Homeland Security started issuing letters affirming the "essential worker" status of migrant agricultural workers, many of whom are undocumented (U.S. Department of Homeland Security 2020), yet such "status" did nothing to protect these workers from arbitrary and cruel 
anti-immigration policies and constant threats of detention and deportation by the Trump administration (Preston and Calderon 2020). Similarly, following a spike of COVID-19 cases among Mexican farmworkers in Canada, Mexico temporarily placed a ban on farmworker migration, and only lifted the prohibition once Canada adopted minimum measures of protection (Haig 2020).

The plight of workers, especially of undocumented migrants, during the pandemic has elicited greater attention of the international community: UN experts have called for governments to implement protections for exploited migrant workers in India (United Nations Human Rights Office of the High Commissioner 2020a) and in Spain (United Nations Human Rights Office of the High Commissioner 2020b) the UN Committee on Migrant Workers and the UN Special Rapporteur on the rights of migrants issued joint guidance in May 2020 to caution governments on the disproportionate impact of the pandemic on migrants and their families (United Nations Committee on Migrant Workers and UN Special Rapporteur on the human rights of migrants 2020).

Yet, even if countries acknowledge these actions during the pandemic, there are presently no realistic prospects that agricultural workers will receive the necessary attention and protections in the future without further action. In fact, to date, states have proven either unwilling or ill equipped to pursue such action on their own. For example, 130 countries have still taken "no action" on the International Convention on the Protection of the Rights of All Migrant Workers and Members of their Families.

A wave of racial justice protests across the US and Europe has also confirmed that national law and policies continue to perpetuate the insidious, structural racism that has long been pervasive in society and food systems. Holding states criminally accountable for the disregard of food system workers' rights and for inaction in the face of discriminatory action is a necessary step forward in light of this reality. The following section addresses how some of these violations have previously been handled by the private sector and governments, and reveals the need for a state crime that imposes greater accountability on the part of states.

\section{Limited Avenues of Redress for Rights Violations of Workers: States and Private Sector Actors remain Unaccountable}

The COVID-19 pandemic made clear that food supply chain workers are subject to severe human rights and labour rights violations. Such violations have been exasperated during the pandemic due to long-standing power inequalities and exploitative working conditions. Food and beverage delivery workers were lauded as the heroes of urbanites living in crowded cities who have the luxury of working at home; yet, on a daily basis, these workers are exposing themselves to the 
pandemic, just so that they can feed themselves. The dangers of this "trade-off" forced on food system workers during the pandemic have also been observed in meat processing plants, fruit and vegetable picking and packaging places, as well as in the production of goods such as palm oil or seafood. ${ }^{15}$

Since the virus outbreak and even before, the precarious situation of workers has become the subject of debate in courts. While the judicial system (and occasionally, administrative channels) has the potential to shape the provision of legal protections on a broad scale, it is also designed to be the last line of defence in upholding rights. States and private sector actors, however, have proven that they are unwilling to enact systemic change in furtherance of the human and labour rights of workers. Thus, without sufficient safeguards in place, or implementation of protective measures, the courts are responding to complaints of violations and fragmented protections that ultimately could have been avoided through meaningful state action. Further, many of these complaints concern the private sector's obligations to workers, thus excluding state responsibility from the conversation.

The following section offers a sampling of court cases brought in Europe and the US, from both before and during the pandemic, that concern workers' rights. Even though these actions have the potential to dictate protections or assign redress, they also highlight the need for greater state accountability.

\section{Case study: Europe}

In the pre-COVID-19 period, there were already several "gig economy" lawsuits in Europe regarding the status of those employed by food delivery companies. The decisions have largely served to excuse employers from offering benefits that otherwise would be required if workers were considered employed by the company and not just "independent contractors." In 2017, a case brought by the Independent Workers Union of Great Britain to the UK Central Arbitration Committee, a body that resolves worker disputes, said that food delivery firm Deliveroo riders were self-employed contractors as they had the right to allocate a substitute to do the work for them. Italy also addressed this question in 2018 with similar results. In June 2020, however, the Milan court put Uber Eats into receivership for exploiting migrant workers, mostly from African war-torn countries (Ansa 2020). This development indicated that post-COVID-19, courts are aware of exploitation and violation of human rights and ready to take vigorous action.

\section{Case study: United States}

Courts in the US have been slightly more active in responding to claims of persistent and pervasive exploitation of workers. For years prior to the pandemic, for example, the U.S. Equal Employment Opportunity Commission (EEOC) handled 
several complaints brought by farmworkers because of discrimination and retaliation. ${ }^{16}$ Since the outbreak of COVID-19, however, an increasing number of lawsuits have been brought on behalf of food system workers. In April 2020, United Farmworkers and Familias Unidas por la Justicia (AFL-CIO) filed a suit in Washington State, calling for an injunction requiring the Department of Health and Labor and Industries to commence emergency updates to health and safety standards meant to protect agricultural workers in the state (Sherman 2020).

A spike in wrongful death lawsuits concerning pandemic-related deaths of food system workers has also shown the lack of protections provided by states. Tyson Foods Inc., for example, has faced legal repercussion following the outbreak of COVID-19 at its facilities. Lawsuits have alleged that the company failed to provide workers with appropriate personal protective equipment, that the company failed to institute adequate workplace safety measures, and that supervisors allowed or encouraged sick or symptomatic workers to continue working. Such cases will test the limits of the U.S. Defense Production Act as a protection for companies, as workers and their families impacted by COVID-19 seek to hold their employers liable.

Administrative agencies tasked with fulfilling state obligations towards workers are facing increased pressures to account for apparent violations, especially in the wake of protests calling for an end to police brutality against African Americans. In July 2020, the Food Chain Workers filed a Title VI Complaint under the Civil Rights Act of 1964 alleging racial discrimination by Tyson Foods Inc. A nationwide coalition of organizations subsequently filed an administrative civil rights complaint with the U.S. Department of Agriculture alleging that Tyson Foods Inc. and JBS, another big meat processing company, engaged in racial discrimination through workplace policies during the pandemic. ${ }^{17}$ The complaint alleges that the companies adopted policies that are contrary to Centers of Disease Control guidance (for example, social distancing) on meat processing lines, thus exposing predominantly Black, Latino, and Asian workforce to risk of COVID19. The complaint asks the U.S. Department of Agriculture to suspend, terminate, and refuse financial assistance (administered through the Federal Farm Bill nutrition program and Trade Mitigation Program contracts) and refer to the Department of Justice for action (O'Shea and Chow 2020).

Whether the government will take action to rectify these abuses and ensure the protection of food system works is yet to be seen. What is apparent from these legal actions, however, is that states are remaining relatively unscathed in the process. Much of these debates on violations are limited to the role of private sector actors, with states being involved only to assign responsibility, facilitate damages, or administer a punitive response. States themselves, however, are largely avoiding accountability for failure to adopt non-discriminatory, inclusive protections 
for all workers, especially those of migrant and minority status, and for being complicit as workers' fundamental rights are subsequently violated.

\section{Conclusion: A Path towards Defining Workers' Rights Violations as a State Crime}

For too long, food system workers, an essential component of our global labour force, has long been "invisible" in the eyes of governments, and even of mainstream human rights NGOs. ${ }^{18}$ Food system workers are often excluded from the agendas of global food policy-makers; yet it is individuals from this marginalized, ignored faction, who toil long hours in the fields, and on whose backs we have built the global trade of food. It is also these workers who remain among the most food insecure, facing formidable barriers to the realization of their right to food. This is not a negligible group, but 1.3 billion people, or approximately one third of the world's workforce who are subject to this pattern of historic neglect, despite their critical role in ensuring that people have uninterrupted access to adequate, available food.

While the COVID-19 pandemic has reminded states of the critical role that agricultural workers play in promoting global food security, the measures adopted in response to the pandemic have focused on keeping food prices stable while ensuring that there are no disruptions of food in the global supply chain. The human rights and labour rights of the food system workers continue to be forgotten, and their wellbeing and health have been sacrificed and continuously jeopardized to satisfy commercial interests. This article has highlighted case studies from the EU and the US, which have adopted measures to ensure uninterrupted access to a largely migrant workforce. These measures have protected the profitability of large food corporations by not requiring corporations to protect the economic, social, legal, and medical wellbeing of their workers.

The formalization of a new state crime offers a potential avenue to hold governments accountable when they remain complicit in the mistreatment of food system workers. Applying state crime theory to this situation would account for two distinct drivers that are perpetrating abuse of workers: first, is the unmonitored pursuit by private actors to minimize the protection of these workers as a means to cut costs and ensure profitability; second, is the practice of states to embrace free market economy rules and global competition without adopting adequate safeguards for workers. States lack the political will or incentives to adopt preventative protections, implement monitoring mechanisms, and enforce against abuses against food system workers. There are almost no assurances in national law or practice that guarantee agricultural workers the medical attention and health 
protection that they need and deserve. Accordingly, private corporate actors and civil society are led to believe that such treatment is acceptable, if not inevitable.

Given that existing laws and regulations are not enforced effectively, this new state crime should not be interpreted in a rigid and legalistic manner. Rather, consistent with the literature on state crime, the main alternative to a legalistic definition is one that defines crime with reference to human rights. ${ }^{19}$ The ICESCR recognizes that all persons are entitled to economic, social, and cultural rights and obligates governments to protect, respect, and fulfil without discrimination. These rights pertain to the wellbeing of people, and include rights to food, shelter, health, social security, and decent work, as proclaimed in Article 22 of the UDHR. In 1966 the concept of "livelihood" was articulated as legally binding articles in the Covenant of Economic Social and Cultural Rights (ICESCR, Article 11, 12 etc.). The ICESCR provides legal protection against severe violations of these fundamental rights and such violations should be treated as harmful acts against people

Unfortunately, countries have decidedly favoured civil and political rights, as opposed to economic, social and cultural rights, which are considered "second generation" rights - a prioritization that can be traced back to the Cold War atmosphere and ideological differences between capitalism and communism. At the 2003 Human Rights Summit in Vienna, the equal treatment of all human rights was strongly emphasized, however, the economic, social, and cultural rights are still left behind, especially in the West. Over the years, the gap between the two sets of rights has increased in parallel to the divisions between developed and developing countries. This has occurred despite the fact that the 2012 Optional Protocol to the Economic Social and Cultural Rights entered into force, which does encourage implementation. As a result, there is a weak disposition of states to monitor compliance with the ICESCR. NGOs, too, have not undertaken such monitoring, and may lack the capacity to do so systematically (Henkin 1995: 224).

State crime theory responds to the fact that, while state responsibility is conceptually helpful, it is not necessarily effective in practice without the additional pressure exerted by strong accountability mechanisms. The diversity of claims brought before courts and administrative bodies in the EU and the US in response to workers' rights violations illustrates a demand for meaningful accountability. The minimal success and reach of these cases demonstrates that the legal system of protection remains far too inaccessible, fragmented, and arbitrary. It is past time to adopt a new state crime that hold states accountable for failing to afford legal protections for all food system workers and for feigning ignorance of the oppression and discrimination to which undocumented, migrant, and minority status workers are disproportionately subject. 
We are experiencing an extraordinary time and we need an extraordinary showing of global solidarity. Thus, given the reluctance of states to take responsibility for grave violations of economic, social, and cultural rights, the authors also propose to add abuse of food system workers to the Statute of the International Criminal Court enumerations of crimes against humanity as listed in Article 7. Such an additional crime might be given the name "severe and systematic abuse of workers." Admittedly it is difficult to reach agreement on criminalization of abusive patterns of state behaviour given the state behaviour of our time. While it might be difficult under normal circumstances to propose such a drastic remedy, the COVID-19 pandemic has showed that the international community must take drastic action to protect those who are most vulnerable.

Even though there will be resistance by states to bring criminal responsibility, civil society can push states forward to recognize the violations of food system workers' rights as a crime that must be taken seriously. It is clear that there is no silver bullet when it comes to protecting the human rights of workers. As a first step, however, we must do more to acknowledge the additional stress placed on this essential population as a result of the global pandemic. States and private sector actors must adopt safeguards and necessary protections to ensure that these workers are not facing intensified abuse while safeguarding their livelihoods and making an essential contribution to feeding the rest of the world.

The pervasive discrimination and rights violations engrained in our food systems have existed for far too long, and will likely persist long after the pandemic. As this global emergency creates new challenges for governments, at least states are doing one thing correctly: classifying food system workers as "essential." Now, it is time to protect these workers accordingly, as they deserve.

\section{Notes}

1. The food system includes all processes involved in keeping us fed: growing, harvesting, processing (or transforming or changing), packaging, transporting, marketing, consuming and disposing of food and food packages. Food systems workers include entire employment relations in this process.

2. The authors deliberately use a concept of "food systems" to include various elements and activities that relate to the production, processing, distribution, preparation, and consumption of food, as well as the output of these activities including socioeconomic and environmental outcomes. See HLPE (2020), p. IV.

3. See Elver (2018) and Elver (2020) Special Rapporteur on the Right to Food, Report to the Human Rights Council, UN Doc. A/HRC/40/56.

4. Estimating that 130 million people may be pushed into chronic hunger by the end of the 2020 due to the pandemic.

5. Forced Labour Convention, 1930 (No. 29) and Protocol of 2014, Freedom of Association and Protection of the Right to Organize Convention, 1948 (No. 87), Right to Organize and Collective Bargaining Convention, 1949 (No. 98), Equal Remuneration Convention, 1951 (No. 100), 
Abolition of Forced Labour Convention, 1957 (No. 105), Discrimination (Employment and Occupation) Convention, 1958 (No. 111), Minimum Age Convention, 1973 (No. 138), Worst Forms of Child Labour Convention, 1999 (No. 182).

6. See ILO 2020b.

7. States have the option of extending the Convention's coverage to include vessels less than $24 \mathrm{~m}$.

8. For example, as of 2020, the Work in Fishing Convention, 2007 (No. 188) was ratified by 18 states, the Plantations Convention, 1958 (No. 110) was ratified by 12 states, and the Safety and Health in Agriculture Convention, 2001 (No. 184) was ratified by 18 states. See ILO, Ratification by Convention, www.ilo.org/dyn/normlex/en/f?p=1000:12001:::NO::.:

9. See statement by Hilal Elver, United Nations Special Rapporteur on the right to food, on her visit to Italy, 20-31 January 2020 (Rome, 31 January 2020), www.ohchr.org/EN/NewsEvents/Pages/ DisplayNews.aspx?NewsID=25512.

10. Modern slavery is the severe exploitation of other people for personal or commercial gain; 40 million people are estimated to be trapped in modern slavery worldwide. See: www.antislavery.org/ slavery-today/modern-slavery/.

11. See also Hilal Elver, Special Rapporteur on the Right to Food, Report to the Human Rights Council, UN Doc. A/HRC/40/56 (citing to A/HRC/30/35, para. 26, and A/HRC/33/46, paras. 17 and 30).

12. See, for example, Kate Hodal and Chris Kelly, "Trafficked into slavery on Thai trawlers to catch food for prawns", The Guardian, 10 June 2014; Robin McDowell, Margie Mason, and Martha Mendoza, "AP investigation: slaves may have caught the fish you bought", Associated Press, 25 March 2015; Ian Urbina, “'Sea slaves': the human misery that feeds pets and livestock”, New York Times, 27 July 2015; Human Rights Watch, "Hidden chains: rights abuses and forced labour in Thailand's fishing industry", 23 January 2018.

13. Note that China, South Korea, and Indonesia have not ratified the ILO Work in Fishing Convention.

14. "Structural racism refers to the ways in which social structures and institutions, over time, perpetuate and produce cumulative, durable, race-based inequalities. This can occur even in the absence of racist intent on the part of individuals." See: See https://foodfirst.org/wp-content/uploads/2016/03/ DR1Final.pdf.

15. Examples of abuse of workers and forced labour around the world can be found from the Business \& Human Rights Resources Center. Available at: www.business-humanrights.org/en/sectors/ agriculturefoodbeveragetobaccofishing.

16. See, for example, U.S. EEOC, "Del Monte Fresh Produce Agrees to Settle EEOC Farmworker National Origin Lawsuit" (18 November 2020), www.eeoc.gov/newsroom/del-monte-freshproduce-agrees-settle-eeoc-farmworker-national-origin-lawsuit; Farm Workers Rights Division of Georgia Legal Services Program, “J\&R Baker Farms to Pay $\$ 205,000$ to Settle EEOC Race and National Origin Discrimination Lawsuit" (6 July 2016), https://farmworkerrights.org/tag/ discrimination/.

17. Complaint under title vi of the civil rights act of 1964, 42U.S.C. $\S \S 2000 d-2000 d-7 ; 7$ C.F.R. $\S \S 15.1-15.12$.

18. Press release of the report of Special Rapporteur by Elver on Agricultural workers A/73/164 (2018) available at: https://www.ohchr.org/en/NewsEvents/Pages/DisplayNews.aspx?NewsID=23754 $\&$ LangID $=$ E (accessed 30 November 2020).

19. There are two very different human rights based definition of state crime: the "torture paradigm" versus the "health paradigm," the former emphasizing civil and political rights, the latter economic, social, and cultural rights. See Penny J. Green and Tony Ward (2000) "State Crime, Human Rights, and the Limits of Criminology", Journal of Social Justice, 27(1): 103. 


\section{References}

Africa Report (2020) “'The Invisibles': Unseen footage of Italy's migrant labourers at peak of COVID19”, The Africa Report, 3 July. Available online at: www.theafricareport.com/32086/the-invisiblesunseen-footage-of-italys-migrant-labourers-at-peak-of-covid-19/ (accessed 20 September 2020).

Ansa (2020) "Uber Italy put into receivership for exploiting migrant riders", InfoMigrants, 6 March. Available online at www.infomigrants.net/en/post/25135/uber-italy-put-into-receivership-forexploiting-migrant-riders (accessed 20 September 2020).

Borges, N., and Huet, N. (2020) "Invisible workers: Underpaid, exploited and put at risk on Europe's farms", EuroNews, 22 July. Available online at: www.euronews.com/2020/07/17/invisible-workersunderpaid-exploited-and-put-at-risk-on-europe-s-farms (accessed 20 September 2020).

Centers for Disease Control and Prevention (2020) "Update: COVID-19 among workers in meat and poultry processing facilities: United States, April-May 2020", 10 July. Available online at: www. cdc.gov/mmwr/volumes/69/wr/mm6927e2.htm (accessed 20 September 2020).

Connelly, T. (2020) "EU leaders requested continued mobility of seasonal agri-workers", RTE, 21 April. Available online at: www.rte.ie/news/coronavirus/2020/0421/1132847-covid19-coronavi rus-eu-migrant-workers/ (accessed 20 September 2020).

Corrado, A. (2018) "Is Italian agriculture a 'pull factor' for irregular migration: And, if so, why?", Open Society European Policy Institute. Available online at: https://cadmus.eui.eu/bitstream/ handle/1814/60950/is-italian-agriculture-a-pull-factor-for-irregular-migration-20181205. pdf?sequence $=1 \&$ isAllowed $=y$ (accessed 20 September 2020).

D’Agostino, L. (2020) “'Cynical': Critics slam Italy's amnesty for undocumented migrants”, $A l$ Jazeera, 30 May. Available online at: www.aljazeera.com/news/2020/05/critics-slam-italyamnesty-undocumented-migrants-200526104154789.html (accessed 20 September 2020).

Elver, H. (2018) "Interim Report to the General Assembly", Special Rapporteur on the Right to Food, UN Doc. A/73/164: 27, 56.

Elver, H. (2020) "Final Report to the Human Rights Council", Special Rapporteur on the Right to Food, UN Doc. A/HRC/43/44: 69.

European Union Agency for Fundamental Rights (2019) "Protection migrants workers from exploitation in the EU: Workers' perspective", EU Agency for Fundamental Rights, 2019, Luxembourg. Available at https://fra.europa.eu/en/publication/2019/protecting-migrant-workers-exploitationeu-workers-perspectives (accessed 20 September 2020).

Food and Agriculture Organization, International Fund for Agricultural Development, World Bank, and World Food Programme (2020a) "Joint statement on COVID-19 Impacts on Food Security and Nutrition", 21 April. Available online at: www.fao.org/news/story/en/item/1272058/icode/ (accessed 20 September 2020).

Food and Agriculture Organization, International Fund for Agricultural Development, United National Children's Fund, World Food Programme, and World Health Organization (2020b) "The state of food security and nutrition in the World 2020. Transforming food systems for affordable healthy diets". Available online at: https://doi.org/10.4060/ca9692en (accessed 20 September 2020).

Global Network Against Food Crises and FSIN (2020) "Global Report on Food Crises: Joint Analysis for Better Decisions". Available online at: www.fsinplatform.org/report/global-report-food-crises2020/ (accessed 30 November 2020).

Guerrero, M. (2020) "Foreign farm workers already face abusive conditions. Now Trump wants to cut their wages", In These Times, 15 July. Available online at: https://inthesetimes.com/article/trumpfarm-worker-labor-h-2a-visa-wages-abusive-conditions (accessed 20 September 2020). 
Haig, T. (2020) "Mexico halts ban on farm workers coming to Canada", Radio Canada International, 22 June. Available online at: www.rcinet.ca/en/2020/06/22/mexico-halts-ban-on-farm-workerscoming-to-canada/ (accessed 20 September 2020).

Harvey, F. (2020) "Coronavirus measures could cause global food shortage, UN warns", The Guardian, 26 March. Available online at: www.theguardian.com/global-development/2020/mar/26/corona virus-measures-could-cause-global-food-shortage-un-warns (accessed 20 September 2020).

Henkin, L. (1995) International Law: Politics and Values. M. Nijhoff, Dordrecht and Boston.

Hesson, T. (2020) "Trump suspends entry of certain foreign workers despite business opposition", Reuters, 22 June. Available online at: https://uk.reuters.com/article/us-usa-immigration-workers/ trump-suspends-entry-of-certain-foreign-workers-despite-business-opposition-idUKKBN23T2ZW (accessed 20 September 2020).

High Level Panel of Experts Food Security and Nutrition (2020) Building A Global Narrative Towards 2030, HLPE, FAO, Rome.

Horst, M. and Marion, A. (2019) "Racial, ethnic and gender inequities in farmland ownership and farming in the U.S.", Agricultural Human Values, 36: 1-16.

International Committee of the Red Cross (2019) "Universal Periodic Review (UPR), NGO Alternative Report", 34th Session October-November 2019. Available online at: www.ihrc.org.uk/wp-content/ uploads/2019/03/UPR19marc-italy-final-final.pdf (accessed 20 September 2020).

International Labour Organization (2007) "The flexibility clauses of the Work in Fishing Convention", Working Paper, 315, 188 Geneva. Available online at www.ilo.org/wcmsp5/groups/public/--ed_dialogue/---sector/documents/publication/wcms_618563.pdf (accessed 20 September 2020).

International Labour Organization (2018) Women and Men in the Informal Economy: A Statistical Picture, Third Edition, ILO, Geneva.

International Labour Organization (2020a) "ILO: COVID-19 causes devastating losses in working hours and employment". Available online at: www.ilo.org/global/about-the-ilo/newsroom/news/ WCMS_740893/lang--en/index.htm (accessed 20 September 2020).

International Labour Organization (2020b) "ILO monitor: COVID-19 and the world of work", Sixth Edition, Updated Estimates and Analysis. Available online at: www.ilo.org/wcmsp5/groups/ public/---dgreports/---dcomm/documents/briefingnote/wcms_755910.pdf (accessed 30 November 2020).

International Organization for Migration (2017) "UN migration agency warns of trafficking, labour exploitation, sexual abuse of Rohingya refugees", 14 November. Available online at: www.iom. int/newsdesk/20171114 (accessed 20 September 2020).

Jordan, M. (2020) "Farmworkers, mostly undocumented, become 'essential' during pandemic", The New York Times, 10 April. Available online at: www.nytimes.com/2020/04/02/us/coronavirusundocumented-immigrant-farmworkers-agriculture.html (accessed 20 September 2020).

Kelkar, K. (2016) "When labour laws left farm workers behind and vulnerable to abuse", PBS News Hour, 18 September. Available online at: www.pbs.org/newshour/nation/labor-laws-left-farmworkers-behind-vulnerable-abuse (accessed 20 September 2020).

McVeigh, K. and Firdaus, F. (2020) “'Hold on brother': Final days of doomed crew on Chinese shark fishing boat", The Guardian, 7 July. Available online at: www.theguardian.com/environ ment/2020/jul/07/hold-on-brother-final-days-of-doomed-crew-on-chinese-shark-finning-boat (accessed 20 September 2020).

Onselen, L. (2020) "Farm lobby demands migrant work visa slaves", Australian Economy, Immigration, Macrobusiness, 17 July. Available online at: www.macrobusiness.com.au/2020/07/farm-lobbydemands-migrant-work-visa-slaves/ (accessed 20 September 2020). 
O'Shea, A. and Chow, K.W. (2020) "Press release: Meat workers and allies file complaint challenging meat processing corporation actions, alleging racial discrimination in disastrous COVID-19 response", Public Justice Food Project, 8 July. Available online at: https:/food.publicjustice.net/ press-release-meat-workers-and-allies-nationwide-file-racial-discrimination-complaint-to-chal lenge-meat-processing-corporation-actions-alleging-racial-discrimination-in-disastrous-covid19-response/ (accessed 20 September 2020).

Preston, J. and Calderon, A. (2020) “'We sit in disbelief': the anguish of families torn apart under Trump's deportation policy”, (Marshall Project) The Guardian, 22 June. Available online at: www. theguardian.com/us-news/2020/jun/22/trump-deportation-policy-families-torn-apart (accessed 20 September 2020).

Roberton, T. et al. (2020) "Early estimates of the indirect effects of the COVID-19 pandemic on maternal and child mortality in low-income and middle-income countries: a modeling study" 12 May. The Lancet Global Health, 8(7). Available online at: www.thelancet.com/journals/langlo/article/ PIIS2214-109X(20)30229-1/fulltext (accessed 30 November 2020).

Royte, E. (2020) "Covid-19 is spreading among farmworkers, and it may get worse", Food and Environment Reporting Network, 2 June. Available online at: https://thefern.org/2020/06/covid19-is-spreading-among-farmworkers-and-it-may-get-worse/ (accessed 20 September 2020).

Salyga, J. (2020) "Why migrant farm workers are living four to a caravan in a time of social distancing", Jacobin, 2 May. Available online at: https://jacobinmag.com/2020/05/migrant-seasonalfarm-workers-coronavirus-eastern-europe (accessed 20 September 2020).

Sherman, J. (2020) "Farm worker unions file emergency petition for judicial review, citing urgent need for 'clear and decisive action' to protect WA farm workers", United Farm Workers, 16 April. Available online at: https://ufw.org/lnicividwa/ (accessed 20 September 2020).

South China Morning Post (2020) "Indonesia seizes two Chinese boats after body of man found aboard", 9 July. Available online at: www.scmp.com/news/asia/southeast-asia/article/3092741/ indonesia-seizes-two-chinese-boats-after-body-man-found (accessed 20 September 2020).

Srour, M. (2018) “'Agromafia” exploits hundreds of thousands of agricultural workers in Italy”, Inter Press Services News Agency, 27 July. Available online at: www.ipsnews.net/2018/07/agromafiaexploits-hundreds-thousands-agricultural-workers-italy/ (accessed 20 September 2020).

Sumner, A., Hoy, C. and Ortiz-Juarez, E. (2020) Estimates of the Impact of COVID-19 on Global Poverty, WIDER Working Paper 2020/43. UNU-WIDER, Helsinki. Available at https://www. wider.unu.edu/sites/default/files/Publications/Working-paper/PDF/wp2020-43.pdf (accessed 30 November 2020).

UCLA World Policy Analysis Center (2020) "Prohibiting Racial and Ethnic Discrimination in the Workplace Fact Sheet". Available online at: https:/ph.ucla.edu/sites/default/files/attachments/ Fact\%20Sheet \%20-\%20D\%40W\%20-\%20Race\%20Ethnicity.pdf (accessed 20 September 2020).

United Nations Committee on Economic, Social and Cultural Rights (CESCR) (1999) "General Comment No. 12: The Right to Adequate Food”, (Art. 11 of the Covenant), 12 May: 4, 20.

United Nations Committee on Economic, Social and Cultural Rights (CESCR) (2000) "General Comment No. 14: The Right to the Highest Attainable Standard of Health" (Art. 12 of the Covenant) 11 August E/C.12/2000/4.

United Nations Committee on Migrant Workers and UN Special Rapporteur on the Human Rights of Migrants (2020) "Joint Guidance Note on the Impacts of the COVID-19 Pandemic on the Human Rights of Migrants", 26 May. Available online at: www.ohchr.org/Documents/Issues/Migration/ CMWSPMJointGuidanceNoteCOVID-19Migrants.pdf (accessed 20 September 2020).

United Nations General Assembly (1948) "Universal Declaration of Human Rights", 10 December, 217 A (III). 
United Nations General Assembly (1966a) "International Covenant on Economic, Social and Cultural Rights", Art. 2.2, 16 December, United Nations Treaty Series, vol. 993: 3.

United Nations General Assembly (1966b) "International Covenant on Economic, Social and Cultural Rights”, Art. 11, 16 December, United Nations Treaty Series, vol. 993: 3.

United Nations General Assembly (1966c) "International Covenant on Economic, Social and Cultural Rights", Arts. 6, 7 and 9, 16 December United Nations Treaty Series 993: 3.

United Nations General Assembly (1966d) "International Covenant on Economic, Social and Cultural Rights", Art. 12, United Nations Treaty Series, vol. 993: 3.

United Nations General Assembly (2015) "Transforming our world: the 2030 Agenda for Sustainable Development" 21 October UN Doc. A/RES/70/1.

United Nations Human Rights Office of the High Commissioner (2020a) "COVID-19: Urgent help for India's forgotten migrant workers must follow Supreme Court ruling, say UN experts", 4 June. Available online at: www.ohchr.org/EN/NewsEvents/Pages/DisplayNews.aspx?NewsID=25926 (accessed 20 September 2020).

United Nations Human Rights Office of the High Commissioner (2020b) "Spain: Passing the buck on exploited migrant workers must end, says UN expert", 26 June. Available online at: www.ohchr. org/EN/NewsEvents/Pages/DisplayNews.aspx?NewsID=26007 (accessed 20 September 2020).

U.S. Department of Homeland Security (2020) "Memorandum On Identification Of Essential Critical Infrastructure Workers During Covid-19 Response", Cybersecurity and Infrastructure Security Agency, 19 March. Available online at: www.cisa.gov/sites/default/files/publications/ CISA-Guidance-on-Essential-Critical-Infrastructure-Workers-1-20-508c.pdf (accessed 20 September 2020). 